\title{
PENETAPAN PRIORITAS LOKASI PEMANFAATAN ALAT PERINGATAN DINI LONGSOR DI JAWA BARAT
}

\section{LOCATION PRIORITY DETERMINATION OF UTILIZATION OF THE LANDSLIDE EARLY WARNING DEVICES IN WEST JAVA}

\author{
Wisyanto dan Ahmad Pratama Putra ${ }^{1}$
}

\begin{abstract}
ABSTRAK: Salah satu bagian penting dalam upaya penanggulangan bencana longsor adalah peningkatan kesiapsiagaan melalui pemasangan alat peringatan dini longsor. Pemerintah pusat berencana memasang beberapa alat peringatan dini untuk Wilayah Jawa Barat. Adanya keterbatasan alat yang mungkin diadakan, sedang jumlah lokasi yang perlu dipantau cukup banyak, maka diperlukan suatu langkah penentuan skala prioritas pemasangan terhadap kesemua daerah rawan yang ada. Analisis data terhadap kesemua kondisi titik-titik rawan longsor tersebut, serta dibantu dengan metoda skor dan pembobotan dari 8 parameter penting gerakan tanah, telah ditetapkan 3 titik rawan longsor yang akan dipasang alat peringatan dini longsor. Ketiga lokasi tersebut adalah Kampung Talegong dan Urug, Blok Babakan Sari dan Kampung Margahayu.
\end{abstract}

Kata kunci: Gerakan tanah, peringatan dini, skor dan pembobotan, Jawa Barat.

ABSTRACT: One important part of the landslide disaster management efforts is to increase preparedness through the installation of landslides early warning devices. The central government plans to put up some early warning devices for several areas in West Java. Because of the limit number of the devices that can be installed, and the many locations that need to be monitored, we need a step towards setting priorities installation for all existing vulnerable areas. Analysis of the data related to the conditions of landslides from all landslide prone areas, and assisted with the method of score and weighting of 8 essential parameters of landslides have been done. The result showed the 3 landslides priority areas for the installation of landslide early warning devices. They are Kampung Talegong and Urug, Blok Babakan Sari and Kampung Margahayu.

Keywords: landslides, early warning, score and weighting, West Java.

\section{PENDAHULUAN}

\subsection{Deskripsi Permasalahan}

Wilayah Indonesia yang luas, memiliki kondisi alam yang berbeda dari satu tempat dengan tempat lainnya. Ada tempat yang relatif

\footnotetext{
1. PTRRB - BPPT, Gedung 820, GEOSTECH, PUSPIPTEK, Kota Tangerang Selatan. email: wisyanto@bppt.go.id
}

aman dari ancaman bencana alam, ada yang rawan terhadap ancaman bencana, tetapi ada juga yang rawan terhadap banyak ancaman becana alam. Hal ini sangat dipengaruhi oleh posisi lintang bujur (klimatologi), dominan proses alam eksogenis, proses endogenis atau kombinasi dari beberapa proses. Bencana alam yang terjadi dengan frekuensi tinggi, diantaranya adalah longsor. Peristiwa alam ini akan semakin sering dijumpai pada perioda penghujan. Daerah Jawa Barat merupakan 
provinsi dengan frekuensi kejadian longsor yang tertinggi diantara provinsi lainnya di Indonesia (http://nationalgeo graphic.co.id).

Dalam menyikapi banyaknya kejadian tanah longsor, ada beberapa jenis upaya untuk mengurangi dampak atau bahkan menghindari dari kerugiaan yang mungkin ditimbulkan. Pengupayaannya dapat berupa penguatan lereng (mitigasi struktur), peningkatan pemahaman akan bahaya gerakan tanah, simulasi, gladi (pembangunan kapasitas atau mitigasi non struktural) dan mungkin juga dengan pemasangan alat peringatan dini (peningkatan kesiapsiagaan) ( UN/ISDR, 2005). Dalam upaya pengurangan risiko bencana, seringkali dihadapkan dengan permasalahan dana. Untuk menyikapi akan keterbatasan ini, dipakai strategi penetapan skala prioritas dalam penanganannya. Mungkin itu prioritas dalam macam upaya yang dapat dilakukan, atau juga prioritas daerah yang harus didahulukan penanganannya.

Pada saat pemerintah memutuskan untuk melakukan pemasangan alat peringatan dini longsor, ada kebingungan dalam menetapkan skala prioritas daerah mana yang harus didahulukan. Hal ini muncul karena banyaknya titik yang memerlukan alat peringatan dini ini. Seperti halnya saat pemerintah ingin memasang alat peringatan dini longsor di Jawa Barat. Karena keterbatasan dana atau alat, maka penetapan skala prioritas dengan kriteria yang jelas dapat dilakukan dan akan mengurangi protes dari pihak daerah yang belum tersentuh upaya ini.

\subsection{Maksud dan Tujuan Peneltian}

Maksud dari penelitian ini adalah mengetahui kondisi aspek kunci dari beberapa titik rawan longsor yang dilaporkan oleh beberapa Badan Penanggulangan Bencana Daerah (BPBD) kabupaten. Selanjutnya berdasarkan pertimbangan aspek kunci yang ada, akan ditentukan titik potensial longsor yang harus didahulukan untuk dipasang alat peringatan dini longsor.

\section{METODE PENELITIAN}

Penelitian dimulai dengan pengumpulan data sekunder, dilanjutkan dengan penelitian lapangan dan menganalisis data yang sudah didapatkan, baik data sekunder maupun data lapangan. Selanjutnya pemeringkatan dilakukan untuk menentukan urutan prioritas lokasi pemasangan alat peringatan dini longsor dengan metoda skor dan pembobotan, adapun besaran bobot dan skor didapatkan melalui pendekatan expert judment dengan memberikan pilihan besar bobot kepada pemegang kepada pemegang keputusan (Hobbs, 1980) dalam hal ini ahli bidang kebencanaan geologi.

\section{HASIL DAN PEMBAHASAN}

\subsection{Data dan Analisis}

Kondisi alam Indonesia yang rawan terhadap bencana longsor dibuktikan dengan banyaknya titik-titik bencana longsor yang telah terjadi di Indonesia. Provinsi dengan frekuensi longsor tertinggi adalah Provinsi Jawa Barat. Untuk menanggulangi ancaman longsor ini, salah satunya adalah dengan meningkatkan kesiapsiagaan masyarakat disekitar daerah rawan longsor, khususnya dengan pemasangan alat pantau deteksi dini bahaya longsor. Adanya keterbatasan dana dalam mengimplementasikan pemasangan alat ini, maka perlu dibuat skala prioritas titik-titik mana saja yang mendesak untuk dipasang alat peringatan dini longsor.

Berdasarkan laporan BPBD yang ada di tingkatan kabupaten di Provinsi Jawa Barat, ada 4 kabupaten memiliki ancaman longsor yang perlu diperhatikan segera (Gambar 1). Keempat kabupaten ini adalah Kabupaten Garut, Ciamis, Majalengka dan Kabupaten Tasikmalaya. Di Wilayah Kabupaten Garut ada 4 titik longsor yang dipandang penting untuk dipasang alat peringatan dini longsor, yaitu Kampung Babakan Jambu (Desa Pasir Langu, Kecamatan Pakenjeng), Kampung Neglasari (Desa Sendangsari, Kecamatan Cigedug), Kampung Talegong 
(Desa Sukamulya, Kecamatan Talegong), Kampung Urug (Desa Salaawi, Kecamatan Talegong). Wilayah Kabupaten Tasikmalaya juga ada 4 lokasi yaitu Kampung Margahayu (Desa Sukarasa, Kecamatan Salawu), Kampung Sukasari (Desa Sundawenang, Kecamatan Salawu), Kampung Babakan Sukamaju (Desa Sukamukti, Kecamatan Cisayong), Desa Kotawaringin (Kecamatan Salawu), dimana lokasi yang ada di Desa Kotawaringin ini sudah dipandang tidak perlu dipasang alat karena masyarakat terancamnya sudah direlokasi. Di Wilayah Kabupaten Majalengka ada 3 titik lokasi, yaitu Blok Babakan sari (Cibeureum, Talaga), Blok Gunung Anten (Cimuncang, Malausma) dan Blok Dayekpanjang (Padarek, Lemah Sugih). Adapun yang ada di Wilayah Kabupaten Ciamis hanya ada 2 lokasi, yaitu Blok Desa (Nasol, Cikoneng) dan Blok Pereng (Darmacaang, Cikoneng).

Banyaknya titik rawan longsor, umumnya tidak sebanding dengan dana yang dapat disediakan dalam menanganinya, khususnya dalam hal menempatkan alat peringatan dini longsor. Untuk itu perlu suatu langkah seleksi terhadap semua titik rawan longsor yang ada. Dari setiap titik rawan yang ada diberikan nilai berdasarkan aspek-aspek yang penting didalamnya dan nantinya akan dapat disusun urutan prioritasnya. Selanjutnya dengan susunan prioritas (pemeringkatan) yang ada, akan dapat dengan mudah ditentukan titik-titik mana yang akan dipasang alat.

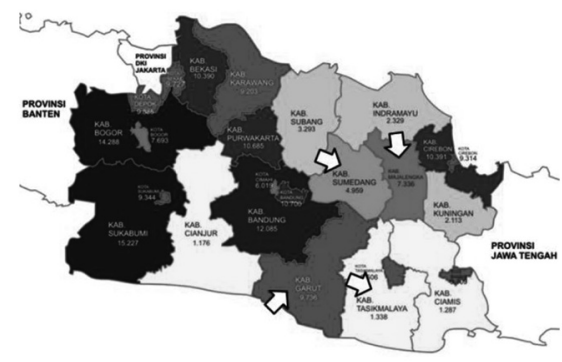

Gambar 1. Peta lokasi ke 4 Kabupaten (anak panah) yang dipertimbangkan sebagai tempat pemasangan alat peringatan dini longsor.

Sumber: Pusdalisbang-Jabar, 2008.
Banyak parameter yang dapat dilibatkan dalam analisis prioritas penempatan alat peringatan dini longsor. Dengan mempertimbangkan tingkat sensitifitas parameter dan kelancaran dalam operasional alat, maka diputuskan ada 8 parameter yang akan dipakai sebagai bahan analisis pemeringkatan pemilihan lokasi rawan longsor yaitu tipe longsor, kemiringan lereng, jumlah Kepala Keluarga (KK) terdampak, luas daerah terdampak, respon pemerintah daerah, respon masyarakat, akses ke lokasi dan kekuatan signal sellular. Parameter tersebut, bila dikelompokkan terbagi dalam 4 aspek, yaitu aspek kestabilan lereng, yaitu tipe longsor dan kemiringan lerengnya, aspek keterpaparan meliputi jumlah kepala keluarga terdampak dan luas daerah terdampak, aspek jaminan pemeliharaan alat setelah terpasang, meliputi respon pemerintah daerah, respon masyarakat serta kemudahan atau akses ke lokasi dan yang terakhir adalah aspek konektifitas komponen alat dari 1 titik ke titik lainnya atau ke pusat kendali atau pusat pantau.

\section{Titik Rawan Longsor di Kabupaten Garut}

Ada 4 titik rawan longsor yang sudah dirasakan sangat mengganggu dan mengancam masyarakat. Keempat titik rawan tersebut terdapat dalam 3 kecamatan, yaitu Kecamatan Pakenjeng, Cigedug dan Kecamatan Talegong (Gambar 2). Jumlah penduduk (sensus 2014) yang ada di Kecamatan Pakenjeng adalah 69.281 jiwa, Kecamatan Cigedug ada 40.269 jiwa dan untuk Kecamatan Talegong memiliki penduduk 31.594 jiwa. Mengingat penyebaran penduduk tidak merata, makaadakemungkinanbahwakecamatan dengan penduduk yang padat, ternyata penduduk yang terpapar longsor tidak begitu besar. Dengan demikian yang akan dipertimbangkan adalah jumlah penduduk yang terpapar longsornya saja. Masalah jumlah jiwa yang ada, distribusi menurut umur dan jenis kelamin sangat berperan penting dalam menanggulangi bencana longsor. Ada kelompok umur yang sangat rentan terhadap bencana, seperti kelompok umur balita dan kelompok umur usia lanjut. Kedua kelompok umur ini sangat rentan dan bergantung pada kelompok umur lainnya, sehingga bila suatu masyarakat 
mempunyai prosentasi tinggi atas kelompok umur tersebut, maka daerahnya akan semakin rentan terhadap ancaman bencana dan sebaliknya. Titik longsor di Kecamatan Pakenjeng terdapat di Kampung Babakan Jambu, Desa Pasir Langu, tepatnya pada koordinat $07^{\circ} 27,634^{\prime} \mathrm{S}$ dan $107^{\circ}$ 38.653'E. Berdasarkan pengamatan lapangan, kondisi lereng yang bergerak memiliki kemiringan $15^{\circ}-75^{\circ}$.

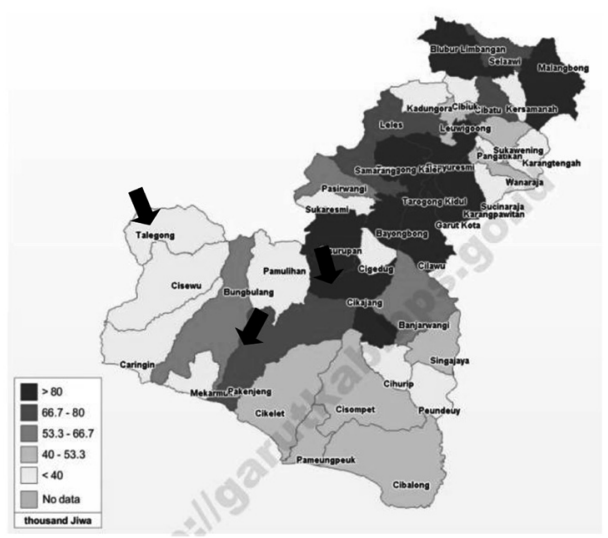

Gambar 2. Lokasi 3 Kecamatan yang membutuhkan alat dan jumlah penduduknya.

Sumber: Garut Dalam Angka 2015.

Jumlah KK yang berpotensi terdampak oleh longsor sebanyak $2 \mathrm{KK}$ dan 1 masjid, meskipun demikian luas daerah yang terdampak meliputi area seluas 2 Hektar $(\mathrm{Ha})$. Respon pemerintah daerah ternyata sangat baik demikian juga dengan respon masyarakatnya yang baik. Hal ini sangat baik bagi keberlangsungan pemeliharaan alat agar dapat terjaga dengan baik. Adapun lokasi longsor termasuk dalam klasifikasi sulit sehingga, bila ada kerusakan atau kendala lain terjadi dan ahli dari pusat harus datang, akan mempersulit proses perbaikan alatnya. Hal lain yang berpengaruh dalam mendukung baik-tidaknya dipasang alat peringatan dini adalah faktor signalnya. Karena ini dibutuhkan untuk mentransfer data dari lokasi ke pusat pengolahan atau pusat pantau (BPBD setempat). Hasil uji besar signal di lokasi longsor, menunjukkan bahwa di bawah lokasi longsor besar signal 0 (dari total 5 bar), di mahkota longsor 3-4 bar untuk operator telkomsel, sedang untuk operator lain tidak ada.

Titik longsor lain yang ada di Garut, berada di Kecamatan Cigedug, Desa Sendangsari Kampung Neglasari, tepatnya pada koordinat $07^{\circ} 18.374^{\prime}$ LS dan $107^{\circ}$ 48.730' BT. Gerakan longsor berpotensi nendatan dengan kemiringan lereng antara $60^{\circ}$ sampai $65^{\circ}$. Jumlah keluarga yang berpotensi terpapar adalah sebanyak $25 \mathrm{KK}$ dengan luas areanya, termasuk dengan kebunnya adalah sebesar $1 \mathrm{Ha}$. Tanggapan pemerintah daerah dan masyarakat terhadap kemungkinan dipasangnya alat peringatan dini longsor adalah sangat baik dan akses kesampaian daerahnya termasuk mudah dijangkau. Kondisi signal yang ada di daerah ini untuk telkomsel sebesar 5 bar, indosat 4 bar dan XL juga sebesar 4 bar. Dengan demikian signal sellular untuk komunikasi data adalah sangat baik.

Longsor yang ada di Kecamatan Talegong ada 2 titik longsor yang terpisah sejauh $\pm 2 \mathrm{~km}$. Titik pertama berada di Kampung Talegong, Desa Sukamulya (07 18.070' LS dan $107^{\circ} 30.625^{\prime}$ BT) dan yang lainnya adalah di Kampung Urug , Desa Salaawi $\left(07^{\circ}\right.$ 18.421' LS dan $107^{\circ} 29.074^{\prime}$ BT). Mekanisme gerak longsor di Talegong berupa nendatan, kemiringan lereng $38^{\circ}-45^{\circ}$, dengan jumlah keluarga yang terdampak sebanyak $63 \mathrm{KK}$ dan luas area terdampaknya $10 \mathrm{Ha}$. Respon pemerintah daerah dan masyarakatnya juga sangat baik, demikian halnya dengan kemudahan untuk menjangkau lokasi termasuk dalam kategori sangat mudah, dimana longsor berada di sepanjang jalan raya dan dapat ditempuh dengan roda 4 hanya membutuhkan waktu 45 menit dari Kota Pangalengan. Hasil survei kekuatan signal menunjukkan bahwa tempat dibawah lokasi longsor 0 bar (indosat dan XL), 1-2 bar (Telkomsel) dan di mahkota longsor 3 bar (Indosat), 4-5 bar (Telkomsel). Adapun longsor yang di Kampung Urug mempunyai peluang gerak campuran yaitu nendatan dan rayapan. Kemiringan lereng $53^{\circ}$ dan berpotensi mengganggu $140 \mathrm{KK}$ dengan luas area terdampaknya seluas $15 \mathrm{Ha}$. 
Respon pemerintah sangat baik dan respon masyarakatnya dalam klasifikasi baik. Adapun kesampaian daerahnya adalah sedang. Jarak horisontal sebenarnya dari titik longsor Talegong dengan Urug hanya $2 \mathrm{~km}$, akan tetapi untuk mencapai titik longsor di Kampung Urug ini harus melewati jalan melingkar sejauh $12 \mathrm{~km}$ dan pada saat survei awal, kondisi jalan sangat rusak (parah) sehingga membutuhkan waktu ditempuh 1 jam, sedang pada survei lapangan berikutnya, kondisi jalan sudah diperbaiki dan waktu tempuhnya hanya 15 menit saja.

\section{Titik Rawan Longsor di Kabupaten Tasikmalaya}

Ada 3 titik rawan longsor yang masuk dalam pertimbangan pemasangan alat peringatan dini longsor. Ketiga titik ini adalah potensi longsor di Kampung Margahayu (07 23.528' LS, $108^{\circ} 01.791^{\prime}$ BT) , Desa Sukarasa, Kecamatan Salawu, potensi longsor di Kampung Sukasari $\left(07^{\circ} 22.571^{\prime}\right.$ LS, $107^{\circ} 59.467^{\prime}$ BT), Desa Sundawenang, Kecamatan Salawu dan potensi longsor di Kampung Babakan Sukamaju (07 14.047' LS, $108^{\circ} 07.204^{\prime}$ BT) , Desa Sukamukti, Kecamatan Cisayong. Data kependudukan untuk ketiga kecamatan ini, berdasarkan data sensus penduduk tahun 2015, jumlah penduduk Kecamatan Salawu sebesar 59.593 jiwa dan untuk Kecamatan Cisayong berjumlah 54.626 jiwa (Kabupaten Tasikmalaya Dalam Angka, 2016). Longsor Kampung Margahayu berpotensi untuk bergerak secara merayap dan slumping (nendatan), kemiringan lerengnya $23^{\circ}-70^{\circ}$ dan akan mengancam $33 \mathrm{KK}$ dengan total luas area terdampak sebesar $3 \mathrm{Ha}$. Respon pemerintah daerah dan masyarakatnya sangat baik, demikian juga dengan kesampaian daerahnya adalah mudah. Keberadaan signal selular sebesar 4 bar (Indosat) dan 5 bar (Telkomsel). Ancaman longsor di Kampung Sukasari, Desa Sundawenang, Kecamatan Salawu bergerak merayap dengan kemiringan lerengnya antara $15^{\circ}-20^{\circ}$. Longsor ini mengancam 55 $\mathrm{KK}$ dan area seluas 1,5 $\mathrm{Ha}$. Kemungkinan akan dipasangnya alat peringatan dini ini direspon sangat baik oleh pemerintah daerah, sedangkan sambutan masyarakat termasuk dalam klasifikasi baik saja. Kemudahan akses ke daerah longsor tergolong menengah atau sedang. Signal selular untuk keperluan transfer data di daerah longsor ini, 4 bar untuk Indosat dan 5 bar untuk Telkomsel. Longsor lain yang ada di Kabupaten Tasikmalaya adalah longsor di Kampung Babakan Sukamaju, Desa Sukamukti, Kecamatan Cisayong. Longsor ini terjadi pada lereng dengan kemiringan $60^{\circ}$ dan berpotensi bergerak secara nendatan. Ancaman longsor ini akan berdampak terhadap lebih dari $50 \mathrm{KK}$ dengan luas area sebesar $1 \mathrm{Ha}$. Adapun pemasangan alat peringatan dini ini direspon sangat baik oleh pemerintah daerah, sedang respon dari masyarakat pada tingkatan sedang saja. Daerah potensial longsornya mempunyai kemudahan kesampaian pada klasifikasi sedang dan signal yang ada menunjukkan kekuatan 4 bar dari Indosat dan 5 bar dari Telkomsel. Sebenarnya ada 1 lokasi longsor lagi yang ada di Kabupaten Tasikmalaya, yaitu longsor di Desa Kotawaringin, Kecamatan Salawu. Akan tetapi karena sudah dilakukannya relokasi ke tempat yang lebih aman, maka ancaman longsor ini dapat diabaikan dan tidak dimasukkan dalam pertimbangan pemasangan alat deteksi dini longsornya.

\section{Titik Rawan Longsor di Kabupaten Majalengka}

Rawan longsor di Kabupaten Majalengka yang akan dipertimbangkan menjadi tempat pemasangan alat deteksi dini longsor ada 3 lokasi, yaitu Blok Babakan sari (108.18.03,1 BT dan 7.01.29.4 LS), Desa Cibeureum, Kecamatan Talaga, Blok Gunung Anten (108.15.45,8 BT dan 7.03.30,4 LS, Desa Cimuncang, Kecamatan Malausma dan titik longsor di Blok Dayekpanjang (108.12.51,9 BT dan 6.59.12,2 LS), Desa Padarek, Kecamatan Lemah Sugih. Adapun jumlah penduduk dari ketiga kecamatan tersebut, penduduk Kecamatan Talaga sebanyak 43.960 jiwa, penduduk Kecamatan Malausma sebanyak 41.526 jiwa dan untuk Kecamatan Lemah Sugih berpenduduk 58.158 jiwa. 
Longsor di Babakan Sari mempunyai kemiringan lereng sebesar $10^{\circ}-15^{\circ}$ dengan mekanisme longsor nendatan dan rayapan. Longsor ini berpotensi mengancam 145 KK dan area seluas $2 \mathrm{Ha}$. Respon pemerintah daerah sangat baik terhadap kemungkinan dipasangnya alat deteksi dini longsor, sedang tanggapan masyarakat dapat dikatakan baik dalam meresponnya. Akses untuk menuju lokasi daerah ini mudah dijangkau, sedang untuk pengujian besar signal sellularnya adalah untuk $\mathrm{XL}$ jenis $\mathrm{H}$ sebesar 4 dari 4 bar, sedangkan Simpati 4 dari 4 bar yang ada. Longsor di Blok Gunung Anten, Cimuncang, Malausma berpotensi untuk bergerak secara nendatan dengan kemiringan lereng $15^{\circ}-25^{\circ}$ dan akan mengancam $6 \mathrm{KK}$ dan area seluas $0,5 \mathrm{Ha}$. Respon rencana pemasangan alat ini direspon sangat baik oleh pemerintah daerah dan pada tingkatan respon baik oleh masyarakat setempat. Daerah ini dapat dijangkau dengan kendaraan roda 4 dengan waktu 1 jam dari Kota Majalengka dan dapat diklasifikasikan dalam tingkatan mudah keterjangkauan lokasinya, sedang tes sinyal menunjukkan bahwa untuk $\mathrm{XL}$ jenis $\mathrm{E} \quad 3$ bar dari 4 bar, sedang untuk Simpati 4 bar dari 4 bar. Longsor lain di Kabupaten Majalengka adalah longsor yang terdapat di Blok Dayekpanjang, Desa Padarek, Kecamatan Lemah Sugih. Mekanisme gerak berupa rayapan dengan kemiringan lereng sebesar $2^{\circ}-7^{\circ}$. Seperti halnya dengan kedua longsor sebelumnya, bahwa pemasangan alat direspon sangat baik oleh pemerintah daerah dan direspon baik oleh masyarakat disekitar lokasi. Lokasi sangat mudah untuk dijangkau dan sinyal transfer data menunjukkan XL jenis $\mathrm{H}$ dengan sinyal penuh atau 4 bar dari 4 bar dan untuk Simpati juga penuh yaitu 4 bar dari 4 bar.

\section{Titik rawan longsor di Kabupaten Ciamis}

Ada dua titik potensi longsor di Kabupaten Ciamis yang perlu perhatian segera. Kedua titik longsor ini adalah titik di Blok Desa (108'17' 25.4"BT dan 70 17' 2.3”'LS), Desa Nasol, Kecamatan Cikoneng dan titik di Blok Pereng (108¹6'19,7' BT, 7017'14,6”'LS),
Desa Darmacaang, Kecamatan Cikoneng. Longsor di Blok Desa bergerak secara merayap dengan kemiringan lereng $15^{\circ}-23^{\circ}$ dan berpotensi mengancam $19 \mathrm{KK}$ dan area seluas $4 \mathrm{Ha}$. Rencana ini direspon baik oleh pemerintah daerah dan masyarakat sekitar, serta mudah jangkauan ke lokasinya. Sinyal di daerah ini menunjukkan XLjenis $\mathrm{E} 3$ dar 4 bar dan Simpati 4 dari 4 bar. Titik potensi longsor di Blok Pereng bergerak secara rayapan dan nendatan dengan kemiringan $25^{\circ}-30^{\circ}$ dan mengancam $26 \mathrm{KK}$ dan lahan seluas $5 \mathrm{Ha}$. Seperti halnya dengan apa yang terjadi di Blok Desa, dimana tanggapan pemasangan alat di Blok Pereng ini adalah baik dari pemerintah daerah dan masyarakat, serta jangkauan lokasi termasuk dalam klasifikasi mudah. Hasil test sinyal, hanya dari Esia saja yang ada dan dengan kekuatan sinyal penuh yaitu 4 dari 4 bar.

\subsection{Hasil Pengamatan Lapangan}

Jumlah ancaman longsor yang dipertimbangkan untuk dipasang alat deteksi dini longsor di Jawa Barat ada 13 titik ancaman. Akan tetapi ada 1 titik yang tidak diikutsertakan dalam penilaian pemilihan karena masyarakatnya sudah direlokasi ke tempat yang aman. Dengan demikian hanya ada 12 lokasi titik ancaman yang dipertimbangkan dalam pemilihan tempat pemasangan alat. Telah dilakukan pengamatan lapangan terhadap ke 12 lokasi potensial longsor dan hasil kesimpulan dari pengamatan lapangan terhadap semua ini telah disinggung dalam sub bab sebelumnya, sedangkan untuk sub bab hasil pengamatan lapangan disini, hanya 1 titik rawan longsor saja yang dibahas, yaitu longsor yang ada di Blok Desa.

Morfogi daerah ini berupa perbukitan bergelombang lemah hingga tajam. Potongan melintang tegak lurus jalan raya (jalan aspal) dari arah barat-timur, adalah lembah punggungan dan lembah, dimana jalan aspal seolah-olah berada disepanjang punggungan yang mengarah utara selatan. Lembah yang terendah dibagian barat (sebelah barat jalan 
raya) berupa sawah, sedangkan dibagian timurnya berupa lereng yang miring ke timur dan berakhir pada lembah yang ditempati oleh aliran sungai (Gambar 3). Pada titik tertinggi atau tepatnya disepanjang jalan raya terrdapat beberapa rumah penduduk dan beberapa diantaranya memiliki kolam didekat rumahnya, khususnya untuk sisi jalan sebelah timurnya. Permukiman banyak dijumpai disisi timur ini, perumahan banyak berdiri disini, mulai dari tepat disisi timur jalan raya ini dan terus kearah timur atau bawah. Sedangkan disebelah barat jalan raya tidak banyak dijumpai rumah penduduk. Gawir atau lereng terjal yang dijumpai disini, seperti yang digambarkan dalam Gambar 3, diperkirakan berupa bidang-bidang longsor bagian kepala atau dapat disebut sebagai gawir longsor. Secara nyata disepanjang potongan melintang dari jalan raya sampai ke sungai disebelah timurnya dijumpai ada 2 gawir longsor dan dapat dikatakan secara keseluruhan ini berupa gerakan longsor berjenjang. dengan ukuran yang bervariasi mulai dari kerikil seperti yang nampak pada Foto 4.d dan yang berukuran besar pada Gambar 4.c. Ada beberapa faktor yang menyebabkan kestabilan tanah disini terganggu, diantaranya adalah adanya genangan masa air dari kolam di atas, di tengah bahkan disekitar kaki lereng, adanya komponen batulanau tufaan dan lembah sungai di kaki lereng. Diketahui bahwa pergerakan tanah biasanya dipengaruhi oleh masa air yang ada pada tubuh lereng. Bila masa air tidak diatur dengan baik, terlebih masa air dibagian atas lereng, maka masa air ini akan meresap kedalam tanah dan akan memperberat beban lerengnya (Lestari, 2008). Faktor lain adalah adanya fragmen yang berupa batulanau tufaan, ada kemungkinan batuan dibawah endapan tanah lanau-pasir halus juga ada yang tersusun oleh batu lanau tufaan yang relatif kedap air dan akan berfungsi sebagai bidang-bidang gelincir pergerakan lereng (longsor). Faktor lain yang mendukung terjadinya ketidak setabilan lereng adalah

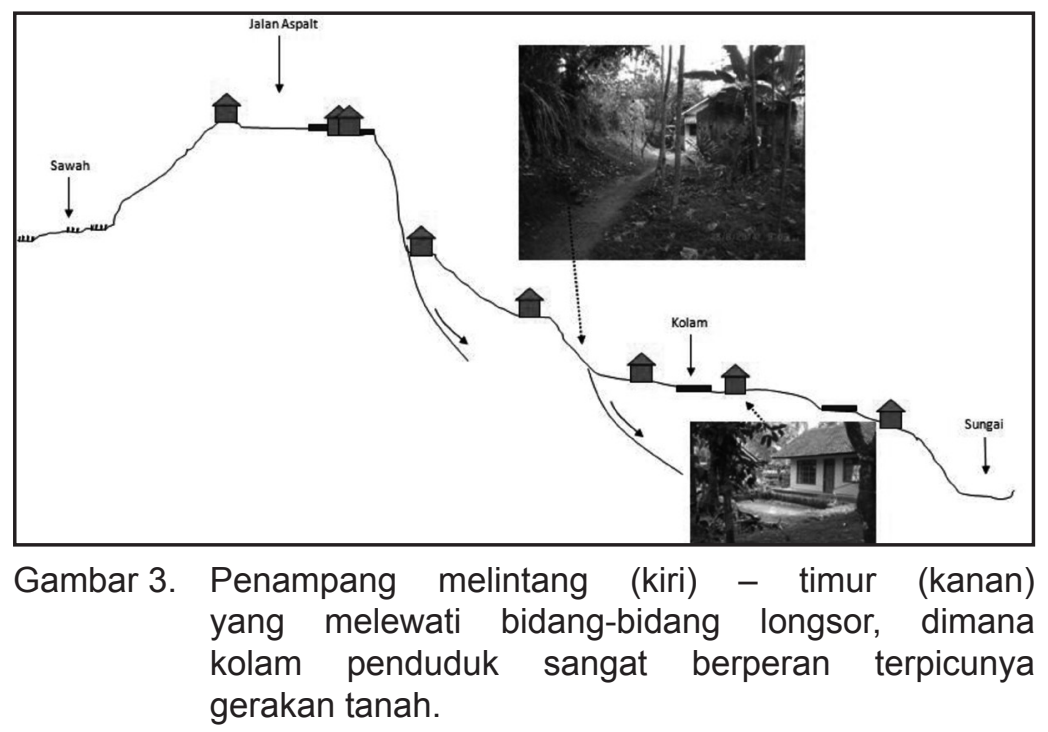

Pengamatan lapangan menunjukkan, bahwa tubuh lereng umumnya tersusun oleh endapan tanah lanau-pasir halus dengan adanya sungai di kaki lereng. Sungai ini telah menggerus dindingnya, sehingga daya dukung fragmen andesit dan batulanau tufaan dinding sungai akan melemah. 


\subsection{Pembahasan}

Adanya ketidak seimbangan antara jumlah lokasi rawan longsor dengan ketersediaan dana untuk pengadaan alat peringatan dini longsor, mengharuskan pemangku kepentingan untuk melakukan seleksi secara ketat. Proses seleksi ini pada kondisi tertentu tidak dapat dilakukan hanya berdasarkan pertimbangan ilmiah saja, mungkin juga ada faktor keadilan di dalam mengambil keputusannya. Pada kasus sekarang, ada 13 lokasi rawan longsor yang perlu dipasang alat. Dari semua rawan longsor ini, ada 1 titik rawan longsor yaitu di Desa Kotawaringin, Kecamatan Salawu, Kabupaten Tasikmalaya yang ternyata sudah dilakukan relokasi, sehingga lokasi ini tidak dimasukkan dalam seleksi penempatan alat. Keduabelas titik rawan longsor yang diseleksi adalah Wilayah Kabupaten Garut ada 4 titik, yaitu Kampung Babakan Jambu (Desa Pasir Langu, Kecamatan Pakenjeng), Kampung Neglasari (Desa Sendangsari, Kecamatan Cigedug), Kampung Talegong (Desa Sukamulya, Kecamatan Talegong), Kampung Urug (Desa Salaawi, Kecamatan Talegong). Wilayah Kabupaten Tasikmalaya ada 3 lokasi, yaitu Kampung Margahayu (Desa Sukarasa, Kecamatan Salawu), Kampung Sukasari (Desa Sundawenang, Kecamatan Salawu), Kampung Babakan Sukamaju (Desa Sukamukti, Kecamatan Cisayong). Wilayah Kabupaten Majalengka ada 3 titik lokasi, yaitu Blok Babakan sari (Cibeureum, Talaga), Blok Gunung Anten (Cimuncang, Malausma) dan Blok Dayekpanjang (Padarek, Lemah Sugih). Adapun yang ada di Wilayah Kabupaten Ciamis hanya ada 2 lokasi, yaitu Blok Desa (Nasol, Cikoneng) dan Blok Pereng (Darmacaang, Cikoneng).

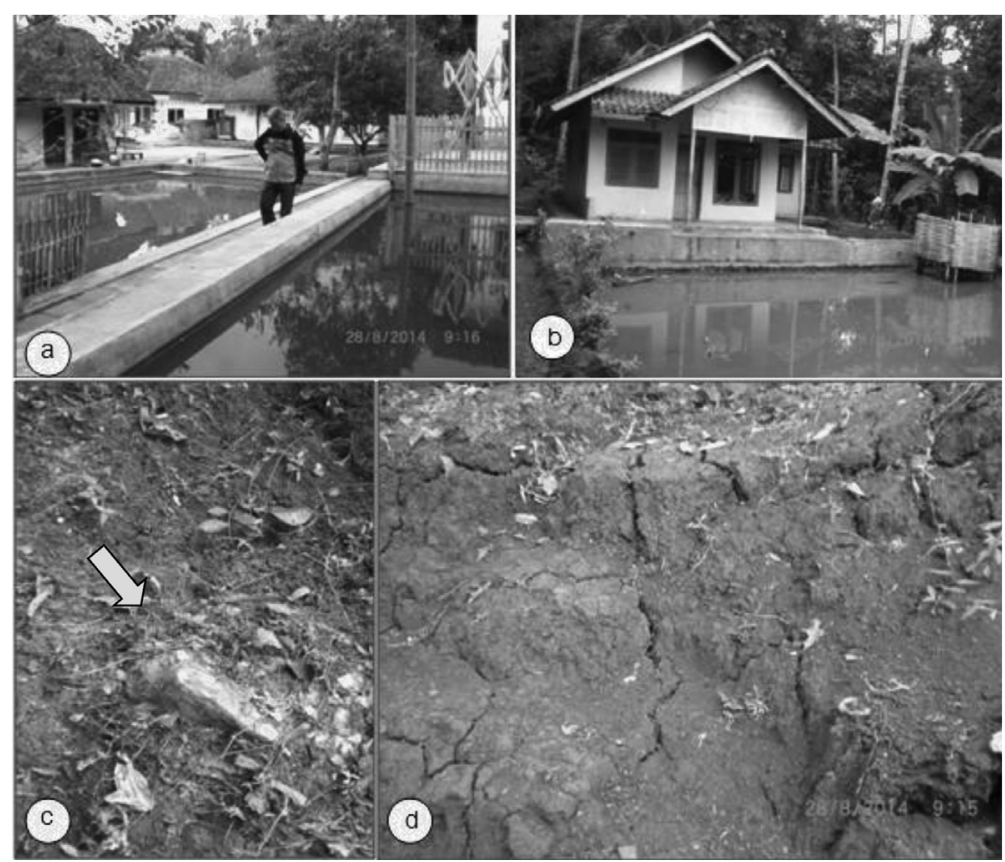

Gambar 4. a. Kolam ikan yang terdapat di bagian atas (potensial head) tubuh longsor b. Kolam ikan di bagian tengah tubuh lereng c. Endapan penyusun lereng berupa tanah lanau-pasir halus dengan fragmen $(\varnothing 20 \mathrm{~cm})$ pasir tufaan d. Endapan lanau-pasir halus (silt-fine sand) dengan fragmen batu andesit dan batulanau tufaan berukuran kerikil $(0,2-1 \mathrm{~cm})$. 
Proses pemilihan dilakukan dengan metoda pemberian skor dan bobot terhadap ke 12 lokasi rawan longsor. Besar bobot untuk setiap parameternya ditentukan oleh beberapa pakar longsor yang terdapat di lingkungan Pusat Teknologi Reduksi Risiko Bencana, BPPT. Saat proses pengambil keputusan mengalami kesulitan dalam menentukan prioritas, penghitungan bobot dan penilaian, dapat dilakukan dengan menggunakan metoda Analytic Hierarchy Process atau AHP (Susilo, 2010). Paramater yang dipakai ada 8 parameter, yaitu tipe longsorannya, kemiringan lereng, jumlah KK yang terdampak, luas area terdampak, respon pemerintah daerah, respon masyarakat sekitar lokasi, keterjangkauan lokasi dan kekuatan signal selular. Penilaian oleh para pakar mengacu pada beberapa pilihan nilai (Hobbs, 1980). Hal ini dilakukan agar memudahkan pakar untuk menetapkan besarannya, serta bagi penulis semakin mudah untuk menyimpulkan hasil kecenderungan besar bobot yang disampaikan para pakar. Setelah dilakukan pendalaman terhadap tingkat kedetilan dari masing-masing parameter oleh penulis dan besar bobot dari pendapat para pakar, maka dapat ditetapkan besar nilai (skor) dan bobot dari masing-masing parameter. Skor ditetapkan sampai 5 klas untuk kesemua parameter, akan tetapi untuk tipe longsor pada dasarnya hanya 3 kelas, yaitu bernilai 1, 3 dan 5. Adapun besar bobot untuk setiap parameternya adalah sebagai berikut: tipe longsoran dengan bobot $10 \%$, kemiringan lereng $10 \%$, jumlah $\mathrm{KK}$ yang terdampak $25 \%$, Luas area terdampak $15 \%$, respon pemerintah daerah $10 \%$, respon masyarakat sekitar lokasi $10 \%$, keterjangkauan lokasi $10 \%$ dan untuk kekuatan signal selular juga 10\%. Adapun untuk skor dari setiap parameter, secara lengkap pembagian kelasnya adalah seperti Tabel 1 berikut:

Tabel 1. Daftar klasifikasi penilaian untuk 8 parameter analisis.

\begin{tabular}{|l|}
\hline Luas daerah terdampak (bobot $\mathbf{1 5 \%}$ ) \\
\hline $1=<1$ ha \\
\hline $2=1 \leq \mathrm{S}<2$ ha \\
\hline
\end{tabular}

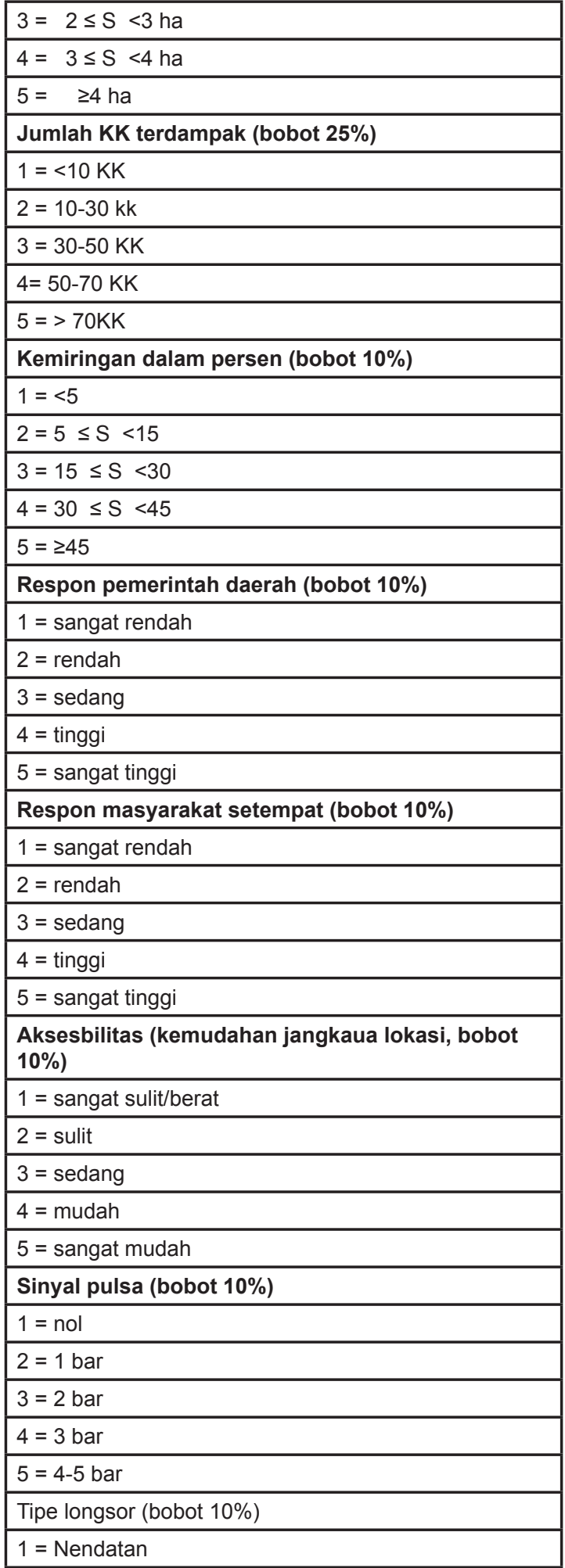


$3=$ Rayapan dan nendatan

5 = Rayapan

Perhitungan dari pemberian nilai (skor) dan bobot terhadap kedelapan parameter yang dipakai, menghasilkan nilai total seperti tertera pada Tabel 2 berikut:

Tabel 2. Daftar hasil pemberian skor dan bobot terhadap ke 12 lokasi longsor Jawa Barat.

\begin{tabular}{|l|l|}
\hline $\begin{array}{l}\text { Kampung Urug, Desa Salaawi, Kecamatan } \\
\text { Talegong, Kabupaten Garut (G4) }\end{array}$ & 4,20 \\
\hline $\begin{array}{l}\text { Kampung Talegong, Desa Sukamulya, Keca- } \\
\text { matan Talegong, Kabupaten Garut (G3) }\end{array}$ & 4,15 \\
\hline $\begin{array}{l}\text { Blok Babakan sari, Cibeureum, Talaga, Maja- } \\
\text { lengka (M1) }\end{array}$ & 3,70 \\
\hline $\begin{array}{l}\text { Kampung Margahayu, Desa Sukarasa, Keca- } \\
\text { matan Salawu, Kabupaten Tasikmalaya (T1) }\end{array}$ & 3,40 \\
\hline \multicolumn{1}{|c|}{ Dan Kampung Babakan Sukamaju, Desa } \\
$\begin{array}{l}\text { Sukamukti, Kecamatan Cisayong, Kabupaten } \\
\text { Tasikmalaya (T3) }\end{array}$ & 3,40 \\
\hline Blok Desa, Nasol, Cikoneng, Ciamis (C1) & 3,35 \\
\hline $\begin{array}{l}\text { Kampung Sukasari, Desa Sundawenang, Ke- } \\
\text { camatan Salawu, Kabupaten Tasikmalaya (T2) }\end{array}$ & 3,30 \\
\hline $\begin{array}{l}\text { Blok Pereng, Darmacaang, Cikoneng, Ciamis } \\
\text { (C2) }\end{array}$ & 3,25 \\
\hline $\begin{array}{l}\text { Kampung Neglasari, Desa Sendangsari, Keca- } \\
\text { matan Cigedug, Kabupaten Garut (G2) }\end{array}$ & 3,20 \\
\hline $\begin{array}{l}\text { Kampung Babakan Jambu, Desa Pasir Langu, } \\
\text { Kecamatan Pakenjeng, Kabupaten Garut }\end{array}$ & 2,60 \\
\hline $\begin{array}{l}\text { Blok Gunung Anten, Cimuncang, Malausma, } \\
\text { Majalengka }\end{array}$ & 2,50 \\
\hline $\begin{array}{l}\text { Blok Dayekpanjang, Padarek, Lemah Sugih, } \\
\text { Majalengka }\end{array}$ & 2,40 \\
\hline
\end{tabular}

Dengan hasil perhitungan di atas, maka dapat ditentukan titik-titik longsor yang diprioritaskan untuk dipasang alat peringatan dini. Pada pelaksanaan pemasangan alat yang dilakukan oleh pemerintah pusat di Jawa Barat ini, telah ditetapkan ada 3 lokasi pemasangan. Dengan demikian, dengan mengacu pada perhitungan dan analisis diatas, ketiga titik longsor yang akan dipasang adalah urutan prioritas 1 sampai 3 pada Tabel 2 di atas, yaitu Kampung Urug, Kampung Talegong dan Blok Babakan Sari. Akan tetapi, seperti yang telah disinggung pada bab sebelumnya, bahwa pada situasi tertentu, tidak hanya pertimbangan ilmiah saja dalam memutuskan kebijakan pemasangan alat, melainkan ada asas keadilan bahkan ada faktor kompromi atau permufakatan dalam proses penetapannya. Dengan menambah faktor keadilan, maka ada 3 kabupaten dari urutan teratas yang akan terpilih. Yaitu Kampung Urug untuk Kabupaten Garut, Blok Babakan Sari untuk Kabupaten Majalengka dan Kampung Margahayu untuk Kabupaten Tasikmalaya.

Desain peralatan untuk setiap lokasi terdiri dari komponen induk dan anak, dimana anak merupakan sensor pada titik-titik kritis tubuh lereng, sedang induk juga dilengkapi sensor, tetapi juga bertindak sebagai penerima data dari anak yang selanjutnya dikirimkan ke kantor atau pusat data. Pada titik lokasi Kampung Urug dan Kampung Talegong, ternyata hanya terpisah sejauh 2 kilometer. Dengan demikian, dua lokasi ini dapat dipandang sebagai 1 lokasi, dimana salah satu diantaranya hanya dipasang anak (dalam hal ini Kampung Urug) tanpa induk, sedang induknya ikut lokasi lainnya yaitu induk yang terpasang di Kampung Talegong. Berdasarkan penilaian yang sudah dilakukan untuk Kabupaten Majalengka, terpilih Blok Babakan Sari. Akan tetapi dengan pertimbangan lain, yaitu masalah perkembangan laju gerak lereng yang ada, potensi longsor Blok Gunung Anten dipandang perkembangan geraknya relatif cepat dan lerengnya terjal, sehingga diharapkan agar Blok Gunung Anten yang dilengkapi alat peringatan dini longsor, meskipun KK yang terancam jauh lebih sedikit yaitu $6 \mathrm{KK}$, dibandingkan dengan 145 KK di Blok Babakan Sari. Seperti diketahui bahwa ada beberapa gerakan tanah mungkin bergerak secara lambat dan akan menimbulkan kerusakan secara gradual, sedang yang lainnya ada gerakan tanah bergerak secara cepat dan dapat menghancurkan bangunan dan jiwa manusia secara tiba-tiba (Mishra, 2011; Ramesh, 2009) seperti halnya yang mungkin akan terjadi untuk jenis longsor di Blok Gunung Anten. Akhirnya, 3 alat yang dialokasikan oleh pemerintah akan dipasang 
pada 3 lokasi dari 3 kabupaten, yaitu:

1. Kampung Talegong dan Kampung Urug dari Kabupaten Garut.

2. Blok Gunung Anten sebagai ganti Blok Babakan Sari dari Kabupaten Majalengka.

3. Kampung Margahayu, Kabupaten Tasikmalaya.

Berdasarkan proses pemilihan yang telah dilakukan, disadari bahwa memang banyak parameter atau hal yang perlu dipertimbangkan dalam menentukan prioritas lokasi pemasangan alat. Tidak hanya faktor keilmiahan saja yang dipakai, melainkan faktor keadilan dan laju perkembangan gerak longsor juga perlu diperhatikan.

\section{KESIMPULAN}

Proses penetapan skala prioritas penempatan alat dapat dilakukan dengan melibatkan 8 parameter penting, seperti tipe longsoran, kemiringan lereng, jumlah KK yang terdampak, Luas area terdampak, respon pemerintah daerah, respon masyarakat sekitar lokasi, keterjangkauan lokasi dan kekuatan signal selular. Meskipun demikian, berdasarkan pengalaman dalam proses pemilihan yang telah dilakukan, disadari bahwa masih ada parameter atau hal lain yang perlu dipertimbangkan dalam menentukan prioritas lokasi pemasangan alat. Tidak hanya kedelapan faktor yang dipakai, melainkan faktor keadilan dan laju perkembangan gerak longsor juga perlu diperhatikan. Dengan sistem pemasangan anak dan induk dalam pengambilan data monitoring longsor dan pengiriman data, dua lokasi rawan longsor yang berdekatan dapat memanfaatkan 1 induk saja, seperti halnya yang dilakukan untuk daerah longsor di Kabupaten Majalengka untuk Kampung Talegong dan Kampung Urug. Akhirnya 3 lokasi pemasangan alat yang ditetapkan adalah Kampung Talegong dan Urug, Blok Gunung Anten dan Kampung Margahayu.

\section{UCAPAN TERIMAKASIH}

Banyak pihak yang telah terlibat dalam penelitian longsor ini. Berkaitan dengan hal tersebut, penulis ingin mengucapkan terimakasihnya kepada beberapa pihak yang telah terlibat, baik dalam diskusi maupun pengamatan lapangan, yaitu seluruh anggota Tim Survei Longsor PTRRB-BPPT (Suryana Prawiradisastra dan Heru Sri Naryanto) dan Tim Survei Longsor Geoteknologi-LIPI (Eko Soebowo, Adrin Tohari, Kori dan Ipan), serta pihak BNPB selaku penyandang dana dalam kegiatan besarnya.

\section{DAFTAR PUSTAKA}

------------, 2016, Kabupaten Tasikmalaya Dalam Angka, Badan Pusat Statistik Kabupaten Tasikmalaya.

-------------, 2015, Laporan Internal Survei Longsor Jawa Barat, Geoteknologi, LIPI.

-------------, 2015, Laporan Internal Survei Potensi Longsor di Jawa Barat, Pusat Teknologi Reduksi Risiko Bencana, BPPT. Mishra, P.K., S. K. Shukla, S. Dutta, S. K. Chaulya and G. M. Prasad, 2011, Detection of Landslide Using Wireless Sensor Networks, Central Institute of Mining and Fuel Research, Barwa Road, Dhanbad - 826015, Jharkhand, India.

Susilo, E., 2010, Sistem Pendukung Keputusan Perijinan dan Penempatan Kolam Jaring Terapung Menggunakan Metoda AHP, Studi Kasus PT PJB Cirata Badan Pengelola Waduk Cirata, Jurusan Teknik Informatika Fakultas Teknik dan IImu Komputer, Universitas Komputer Indonesia, Bandung.

Ramesh, M.V., N. Vasudevan dan J. Freeman, 2009, Real Time Landslide Monitoring Via Wireless Sensor Network, Geophysical Research Abstract, Vol. 11, EGU2009-14061. 
Lestari, F. F., 2008, Penerapan Sistem Informasi Geografis Dalam Pemetaan Daerah Rawan Longsor Di Daerah Bogor, Fakultas Kehutanan, Institute Pertanian Bogor.

-, 2008, Peta Kabupaten Jawa Barat, Pusat Data dan Analisis Pembangunan, Pemerintah Daerah Jawa Barat. , 2005, Living with Risk: A Global Review of Disaster Reduction Initiatives, UN/ISDR.
Hobbs, B.F., 1980, A Comparison of Weighting Methods in Power Plant Siting, Desicion Sciences, vol. 11, issue 4 2015, Kabupaten Garut Dalam Angka, Badan Pusat Statistik Kabupaten Garut.

http://nationalgeographic.co.id/berita/2013/03/ jawa-barat - miliki-zona-rentan-longsorterbanyak 